\title{
Prophylaxis of post-operative nausea and vomiting in major obstetrics surgeries: a comparative study between palanosetron and neit guam point stimulation
}

\author{
Shaily Agarwal*, Apurva Agarwal, Renu Gupta, Pranshi Gupta
}

\author{
Department of Obstetrics and Gynecology, Ganesh Shankar Vidyarthi Memorial Medical College, Kanpur, Uttar \\ Pradesh, India
}

Received: 21 January 2017

Accepted: 28 February 2017

\section{*Correspondence: \\ Dr. Shaily Agarwal, \\ E-mail: drspourush@gmail.com}

Copyright: ( $)$ the author(s), publisher and licensee Medip Academy. This is an open-access article distributed under the terms of the Creative Commons Attribution Non-Commercial License, which permits unrestricted non-commercial use, distribution, and reproduction in any medium, provided the original work is properly cited.

\section{ABSTRACT}

Background: Post-operative nausea and vomiting (PONV) prophylaxis is an important component in providing safe anesthesia in antenatal women. Pharmaceutical interventions like metoclopramide and 5-HT3 antagonists are the current treatment of choice for PONV prophylaxis. However newer drugs are less easily available and more expensive and there is always a concern regarding the effects on fetus. The objective of the study was to evaluate and compare efficacy and safety of antiemetic effects of stimulation of neitguam point stimulation with palonosetron for PONV prevention in obstetric surgeries.

Methods: A randomized control trial was done on 150 patients with ASA grade I-II, between ages of 18-45 undergoing obstetric surgery under spinal anesthesia at a tertiary care center. The patients were randomly allocated into two groups using a random sequence. In group I, 76 patients received $75 \mu \mathrm{g}$ palonosetron IV 5 minutes prior to induction. Group II contained 74 patients in which neitguam point stimulation was done by acupressure (wrist band) . All patients were followed till 24 hours post-surgery and incidence of PONV was recorded intra-operative and till 30 minutes, at 2 hours, 6 hours and 24 hours post-surgery. The results were analyzed using SPSS software and chi square test.

Results: Both neit guam point stimulation and palanosetron were effective in prevention of PONV ( $\mathrm{p}=0.32)$. neit guam point stimulation can be considered as effective as palonosetron in prevention of nausea. The cost analysis signifies the advantage of neit guam point stimulation.

Conclusions: Neit guam point stimulation is a safe and highly effective method to prevent PONV. It can help in bringing down cost and can be easily made at the small primary healthcare centers and trained midwives.

Keywords: 5 HT3 Antagonist, Neit guam point stimulation, Palonosetron, Post-operative nausea and vomiting

\section{INTRODUCTION}

Post-operative nausea and vomiting (PONV) is a common complication after surgery. Incidence of PONV has been described to be as high as $60-80 \%$ in some studies. Multiple studies have emphasized the economic burden of PONV and its effect on post-operative recovery. ${ }^{1}$ The etiology of PONV associated with obstetric surgery is considered multifactorial and includes progesterone-induced reduction in LES (Lower Esophageal Sphincter) tone, increased intra-gastric pressure, hypotension, visceral stimulation, exteriorization of uterus, and use of neuraxial anesthesia. ${ }^{2}$

Obstetric surgery places the patient at a high risk for Intra Operative Nausea and Vomiting (IONV), as well as PONV. Thus, PONV prophylaxis is an important component in providing safe anesthesia for these patients. 
Pharmaceutical interventions like metoclopramide and 5HT3 antagonists are the current treatment of choice for PONV prophylaxis. ${ }^{3}$ However newer drugs are less easily available and more expensive and there is always a concern regarding the effects on fetus. There is a renewed interest in a non-pharmaceutical intervention that can be easily available and simple to use even at remote centers in the country. The neit guam (P6) meridian point has been advocated in acupressure as a stimulation point for reducing nausea and vomiting. This study attempts to evaluate and compare neit guam point stimulation with palonosetron for PONV prevention in obstetric surgery.

\section{METHODS}

A prospective study was conducted on patients undergoing obstetric surgery under regional anesthesia at Obstetrics and Gynaecology Department of G. S. V. M. Medical College Kanpur after clearance from the institute's ethics committee. Patients having renal disorders, diabetes mellitus, BMI $>35 \mathrm{~kg} / \mathrm{m}^{2}$, smokers were not included in the study. 150 patients with ASA grade I-II, between ages of 18-45 years were included in the study. The patients were randomly allocated in two groups. In group I, 76 patients received $75 \mu \mathrm{g}$ palonosetron IV 5 minutes prior to induction. Group II contained 74 patients in which neit guam point stimulation done by acupressure (wrist band). An acupressure wristband was applied at the neit guam point - P6 point (a point on the ventral surface of forearm between the palmaris longus and carpi radialis extensor tendons) For a distance two times wider than the distance of the thumb interphalangeal joint from the distal wrist crease (almost four $\mathrm{cm}$ from the distal wrist crease). ${ }^{4}$ An elastic band of $1.5 \mathrm{~cm}$ width and a circular plastic button at the end for applying pressure to neit guam point was used. This band was applied 5 minutes prior to induction of anesthesia and kept in place for 24 hours post- surgery.

To maintain appropriate blinding, palanosetron were diluted with normal saline to get a five ml injection. Patients in group I were applied a sham band (simple band without any acupressure point stimulating button on it) whereas group II patients were given five $\mathrm{ml}$ normal saline injection. These patients underwent various obstetrical caesarean sections surgeries like (elective and emergency), laparotomy for rupture uterus and ectopic pregnancy. All patients were observed for 24 hours postsurgery and incidence of PONV was recorded intraoperative and till 30 minutes, at 2 hours, 6 hours and 24 hours post-surgery. in case of persistent vomiting even after the use of palanosetron in group 1or neit guam point stimulation in group II dexamethasone and ondansetron. The results were analyzed using SPSS version 20 software. The monitored and calculated data were analysed using student's unpaired $\mathrm{t}$ test and $\mathrm{z}$ test. $\mathrm{P}$ value of $<0.05$ was considered significant.

\section{RESULTS}

The groups were well matched demographically in terms of mean age and weight of the patients and proportions of primigravida patients (Table 1).

Table 1: Patient demographic information.

\begin{tabular}{|llll|}
\hline Variables & Group I & Group II & p value \\
\hline Age (mean) years & 26.33 & 25.86 & 0.076 \\
\hline Weight $($ mean) $\mathrm{kg}$ & 57.34 & 57.78 & 0.627 \\
\hline Primigravida $(\mathrm{n})$ & 78 & 83 & 0.935 \\
\hline
\end{tabular}

The neit guam point stimulation group had 5\% lower incidence of nausea as compared to palonosetron $(\mathrm{p}=0.301)$. Neit guam point stimulation by wristband can be considered as effective as palonosetron in prevention of nausea (Table 2).

Table 2: Incidence of nausea in both groups.

\begin{tabular}{|llllll|} 
Timings & $\begin{array}{l}\text { group I } \\
(\mathbf{n}=76) \\
\text { (palanosetron) }\end{array}$ & $\begin{array}{l}\text { group II }(\mathrm{n}=\mathbf{7 4}) \\
\text { (neit guam } \\
\text { point } \\
\text { stimulation) }\end{array}$ & $\begin{array}{l}\text { p } \\
\text { value }\end{array}$ \\
\hline & $\mathbf{n}$ & $\mathbf{\%}$ & $\mathbf{n}$ & $\mathbf{\%}$ & \\
\hline $\begin{array}{l}\text { IONV, } \\
<30 \mathrm{~min}\end{array}$ & 3 & 3.94 & 2 & 2.70 & 0.326 \\
\hline$<2 \mathrm{hrs}$ & 10 & 13.15 & 9 & 12.16 & 0.442 \\
\hline $2-6 \mathrm{hrs}$ & 2 & 2.63 & 1 & 1.35 & 0.11 \\
\hline Total & $\mathbf{1 5}$ & $\mathbf{1 9 . 7 3}$ & $\mathbf{1 2}$ & $\mathbf{1 6 . 2 1}$ & $\mathbf{0 . 3 0 1}$ \\
\hline
\end{tabular}

The incidence of vomiting was high in palonosetron group $(15 \%$ vs. $7 \%)$ but the difference was not statistically significant $(\mathrm{p}=0.142)$ (Table 3$)$.

Table 3: Incidence of vomiting in both groups.

\begin{tabular}{|lllll|l|}
\hline Timings & \multicolumn{2}{l}{$\begin{array}{l}\text { group I } \\
(\mathbf{n = 7 6})\end{array}$} & \multicolumn{2}{l|}{$\begin{array}{l}\text { group II (n=74) } \\
\text { (neit guam point }\end{array}$} & $\begin{array}{l}\text { p } \\
\text { value }\end{array}$ \\
\hline & $\mathbf{n}$ & $\mathbf{\%}$ & $\mathbf{n}$ & $\mathbf{\%}$ & \\
\hline $\begin{array}{l}\text { IONV, } \\
<30 \mathrm{~min}\end{array}$ & 4 & $5.26 \%$ & 3 & $4.05 \%$ & 0.26 \\
\hline$<2 \mathrm{hrs}$ & 6 & $07.89 \%$ & 3 & $04.06 \%$ & 0.32 \\
\hline 2-6 hrs & - & - & - & - & - \\
\hline Total & $\mathbf{1 0}$ & $\mathbf{1 3 . 1 5 \%}$ & $\mathbf{6}$ & $\mathbf{0 8 . 1 \%}$ & $\mathbf{0 . 1 4 2}$ \\
\hline
\end{tabular}

Both the interventions were equally effective in prevention of vomiting, again highlighting the efficacy of the neit guam point stimulation. Incidence of side effects was slightly higher in palanosetron group (Table 4) but it was not significant statistically (p-0.36). Neit guam point stimulation is extremely cost effective over palonosetron as the number of patients increases (Figure 1). 
Table 4: Incidence of side effects.

\begin{tabular}{|llll|}
\hline Group & Number & Percent \\
\hline Group I (palanosetron) & $\mathrm{n}=76$ & 2 & 2.63 \\
\hline $\begin{array}{l}\text { Group II (neitguam point } \\
\text { stimulation) }\end{array}$ & $\mathrm{n}=74$ & 1 & 1.35 \\
\hline
\end{tabular}

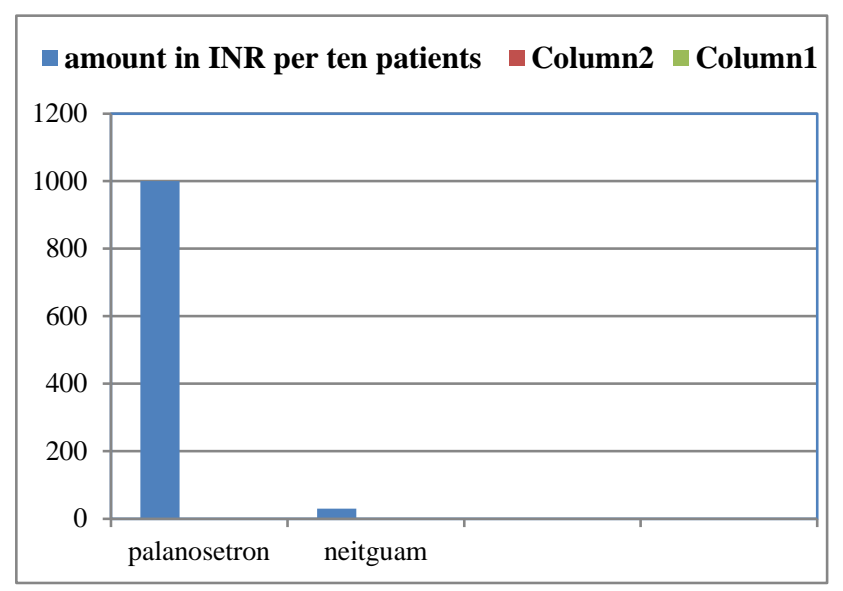

Figure 1: Cost comparison.

\section{DISCUSSION}

PONV prophylaxis has been a subject of multiple studies and meta-analysis but still evades an effective solution. Metoclopramide and 5HT3 antagonists are the mainstays of PONV prophylaxis. However, concerns about cost and side effects have led to interest in non-invasive methods like acupressure. This is especially true in setting of obstetrics where the effect of drug on the fetus and during lactation have to be kept in mind.

Our study shows that neit guam point stimulation by wristband is as effective as the newer and arguably better, 5HT3 antagonist palonosetron. However both the interventions were equally effective in prevention of vomiting.

The neit guam point is the major acupressure point studied however other points studied have been Shenmen (H7) and Shang Wen (CV13)., 5 The exact mechanism of PONV reduction by neit guam point stimulation is not known. ${ }^{3}$ The results in literature have been mixed with some studies showing a significant reduction in PONV whereas some failing to show any major effect. The Cochrane review by Griffth et al clearly showed that neit guam point stimulation reduces the incidence of PONV as compared to sham treatment. There was no difference in efficacy of neit guam point stimulation in prevention of PONV as compared to various pooled drugs as well. ${ }^{3}$ The acupressure wristband was found to be effective in nausea prophylaxis. The incidence was lower than palonosetron group but not statistically significant. Hence it can be implied that wristband is not inferior to palonosetron in prevention of nausea. This fact is important as palonosetron is much more expensive and less easily available than the acupressure band. A cheaper, more readily intervention like band if found efficacious can be preferred over more expensive and difficult to obtain drug like palonosetron.

In contrast to the incidence of nausea, there was no significant difference between the groups in incidence of vomiting. This finding also highlights the reason why nausea and vomiting must be recorded separately to ensure proper recording of results and comparability of the studies, as both these parameters are independent. Acupressure wristband can be considered equally efficacious in prevention of post-operative vomiting as palonosetron.

Good efficacy along with absence of major side effects makes neit guam point stimulation an attractive option in obstetrics anesthesia. Efficacy of neit guam point stimulation in caesarean and other gynecological surgeries, versus a placebo has been established in multiple studies. ${ }^{7}$ However studies comparing acupressure to other drugs in obstetrics surgery have been very few. We could not find any study comparing acupressure to 5-HT3 antagonists and very few comparing acupressure with dopamine antagonists.

\section{CONCLUSION}

The study demonstrates the efficacy of neit guam point stimulation by wristband in PONV prophylaxis for obstetric surgeries in comparison to the new 5-HT3antagonist palonosetron. The acupressure wristband can help in bringing down cost and can be easily made at the small primary healthcare centers and trained midwifes, hence circumventing the issue of drug availability and economic burden. A non-invasive, inexpensive intervention like acupressure can be extremely useful in public health care system in India.

Funding: No funding sources

Conflict of interest: None declared

Ethical approval: The study was approved by the Institutional Ethics Committee

\section{REFERENCES}

1. Gan TJ, Sloan F, de L Dear G, El-Moalem HE, Lubarsky DA. How much are patients willing to pay to avoid postoperative nausea and vomiting? Anesth Analg. 2001;92(2):393-400.

2. Griffiths JD, Gyte GM, Paranjothy S, Brown HC, Broughton HK, Thomas J. Interventions for preventing nausea and vomiting in women undergoing regional anaesthesia for caesarean section. Cochrane Database Syst Rev. 2012;(9):CD007579.

3. Apfel CC, Kranke P, Eberhart LH, Roos A, Roewer N. Comparison of predictive models for postoperative nausea and vomiting. $\mathrm{Br} \mathrm{J}$ Anaesth. 2002;88(2):234-40. 
4. Lee A, Fan LT. Stimulation of the wrist acupuncture point P6 for preventing postoperative nausea and vomiting. The Cochrane Library. 2009.

5. Ming JL, Kuo BI, Lin JG, Lin LC. The efficacy of acupressure to prevent nausea and vomiting in postoperative patients. J Advanc Nurs. 2002;39:343-51.

6. Somri M, Vaida SJ, Sabo E, Yassain G, Gankin I, Gaitini LA. Acupuncture versus ondansetron in the prevention of postoperative vomiting. Anaesth. 2001;56:927-32.

7. Habib AS, Itchon-Ramos N, Phillips-Bute BG, Gan TJ. Transcutaneous acupoint electrical stimulation with the ReliefBand ${ }^{\circledR}$ for the prevention of nausea and vomiting during and after cesarean delivery under spinal anesthesia. Anesth Analg. 2006;102(2):581-4.

Cite this article as: Agarwal S, Agarwal A, Gupta $\mathrm{R}$, Gupta P. Prophylaxis of post-operative nausea and vomiting in major obstetrics surgeries: a comparative study between palanosetron and neit guam point stimulation. Int J Reprod Contracept Obstet Gynecol 2017;6:1440-3. 